\title{
Effects of the Instrument Pilates Exercise Based on the Schroth Exercise on the Cobb's Angle, Angle of Trunk Rotation and Low Back Pain in Patients with Idiopathic Scoliosis: A Single Subject Study
}

Ki Yeon Song', Ki Hyun Baek', Mi Soo Lim', Hyoung-won Lim²

'Department of Physical Therapy, Graduate School, Dankook University, Cheonan, Republic of Korea; ${ }^{2}$ Department of Physical Therapy, Dankook University, Cheonan, Republic of Korea

Purpose: This study examined the effects of the application of Schroth exercise-based instrument Pilates exercise on the Cobb's angle, angle of trunk rotation, and low back pain of female patients with idiopathic scoliosis.

Methods: Three patients with idiopathic scoliosis at a Cobb's angle of $20^{\circ}$ or more participated in this study. Among the single-subject experimental research designs, a reversal (ABA) design was performed. In particular, Schroth exercise-based instrument, Pilates exercise, was performed for 10 weeks, consisting of five weeks between the baseline and intervention one period and five weeks between the intervention 1 and intervention 2 periods, and then followed up for five weeks.

Results: After the Schroth exercise-based instrument, Pilates exercise, was applied, the Cobb's angle and the angle of trunk rotation decreased compared to the baseline in all subjects, and the follow-up period also showed a continuous decline. After Pilates exercise was performed, low back pain in subjects 1 and 2 was decreased in the intervention 1 period compared to the baseline. The level of low back pain in the intervention 2 period increased compared to the intervention 1 period, but a reduction was noted in the follow-up period. The low back pain in the subject was decreased in all intervention periods and the follow-up period.

Conclusion: Schroth exercise-based Pilates exercise improves the Cobb's angle and the angle of trunk rotation for female patients with idiopathic scoliosis in their teens and 20s, and an effective intervention method is proposed for low back pain.

Keywords: Scoliosis, Pilates exercise, Schroth exercise

서 론

과학문명이 발달하고 경제가 성장하면서 생활은 윤택해졌으나, 앉아 있는 시간이 늘어남에 따라 신체활동이 감소하게 되었다. 운동 부족 과 신체 불균형에 대한 인식 부족, 잘못된 스마트폰의 사용, 나쁜 자 세 등은 체형 불균형을 야기하며,' 이로 인한 비구조적(nonstructural) 척추옆굽음증 및 구조적(structural) 척추옆굽음증의 발생빈도가 높 아지고 있다.2

비구조적 척추옆굽음증은 척추 굽이가 가역적이고, 굽이 내 척추 몸통의 회전이나 비대칭 변화가 동반되지 않아 특별한 치료가 필요 하지 않은 경우도 있고, 능동적인 자세 변화를 통해 교정될 수 있다. ${ }^{3}$ 이에 반해 구조적 척추옆굽음증은 형태학적 이상으로 발병하는 옆
굽음증으로, 전체 척추옆굽음증의 약 85-90\%가 정확한 발병 원인이 밝혀지지 않은 특발성 척추옆굽음증(Idiopathic scoliosis)으로 분류된 다. 이러한 특발성 척추옆굽음증은 성장속도가 가장 빠른 청소년기 에 많이 발병하여 뼈대의 성장이 끝날 때까지 진행되는 특성을 가지 고 있다. 척추옆굽음증이 발생하게 되면, 척추뼈 몸통의 정중면, 이 마면상에서의 굽이 및 돌림 변형, 앞면 갈비뼈 봉우리(rib hump)의 돌 출로 인한 외형상의 기형이 나타난다. 외형상 문제뿐만 아니라 잦은 피로감으로 인한 작업능률 저하나 자신의 체형에 대한 불만족 등은 자아 정체감 상실 및 정신 건강의 약화로 이어지며, 심리적 불안으로 인한 우울증 등 심리적, 정신적 장애를 초래하기도 한다. 더 나아가 치료가 지연되어 척추 굽이의 변형이 심화되면 굽이의 변화로 인해 등뼈의 가동성이 제한되고, 가슴우리의 앞. 뒤 직경이 좁아지며, 가
Received Mar 10, 2021 Revised Apr 2, 2021

Accepted Apr 6, 2021

Corresponding author Hyoung-won Lim

E-mail movt12@hanmail.net
Copylight ( 2021 The Korean Society of Physical Therapy

This is an Open Access article distribute under the terms of the Creative Commons Attribution Non-commercial License (https:// creativecommons.org/license/by-nc/4.0.) which permits unrestricted non-commercial use, distribution, and reproduction in any medium, provided the original work is properly cited. 
슴우리와 폐의 성장장애가 나타난다. ${ }^{6}$ 이는 주위 장기를 전위시키거 나 압박하여 호흡근 약화를 초래하게 되고 심폐기능의 장애 및 폐성 심질환(cor pulmonale) 등을 유발해 조기 사망률이 정상인에 비해 2 배 이상 증가하게 된다.

현재 적용되고 있는 척추옆굽음증을 치료하기 위한 방법으로는 신체적 재활운동, 보조기 착용 그리고 척추융합수술이 대표적이다. ${ }^{8}$ 보존적 치료에는 전기자극치료, 견인요법, 보조기 착용, 운동치료, 도 수교정 등 다양한 치료방법들이 소개되어 왔다. 다양한 운동요법 중 필라테스 운동은 몸의 긴장을 풀어주는 동시에 근육을 강화시키는 운동법으로 1900년대에 Joseph H Pilates에 의해 처음 개발되어 오늘 날까지 끊임없이 발전하고 있는 운동법이다. 필라테스 운동 동작들 은 몸 전체를 스트레칭 하듯이 부드럽게 움직여, 몸을 유연하게 하고, 근육을 강화시켜 잘못된 자세를 바로잡아 주고 몸을 균형 있게 가꿔 준다. 또한 특정 근육만을 과도하게 발달시키기보다는 단계별로 신체 를 단련시킨다. ${ }^{9}$ 특히 전신의 근육들 중 신체 중앙에 위치하는 파워 하우스(powerhouse) 근육을 단련시켜 척추를 안정화시키고, 신체 중 심을 안정화시키는 근육들을 활성화시킨다. ${ }^{10}$ 이는 복부 운동만으로 단련하기 어려운 허리 앞쪽과 뒤쪽의 근육을 단련시킴으로써 자세 를 교정하고 균형을 이루도록 하여 신체의 움직임을 효율적으로 통 제하고 조절한다. ${ }^{11}$

필라테스를 이용한 운동치료가 척추옆굽음증의 개선, 허리 부위 의 근력 및 유연성 향상, 호흡량이나 평형성 같은 운동수행 능력 향 상, 전반적인 체력 증진에도 긍정적인 효과가 있다는 선행연구 결과 는 이미 많이 보고되고 있다.12 이전 연구에서는 허리 통증 예방 및 기 능 향상을 목표로 하는 연구가 많았으며, 운동을 통한 근력강화와 코 어의 안정성, 유연성 증진과 바른 자세 교정연구에 초점이 맞춰져 있 었다. ${ }^{33} 20$ 대 척추옆굽음증 여성에게 8 주간 필라테스 운동을 적용한 결과 허리 근력이 강화되고 신체 유연성이 증진되었다는 보고 ${ }^{14}$ 와 여 중생을 대상으로 필라테스 운동을 적용했을 때 Cobb's angle의 감소 와 유연성 및 균형능력 향상과 근육량 증가의 효과가 있었다는 연구 결과 ${ }^{15}$ 가 있고, 초등학교 여학생과 중년 여성을 대상으로 필라테스 운동프로그램을 진행한 연구논문에서는 긍정적인 효과를 보고하 며, 1,17 척추옆굽음증을 위한 중재로 필라테스를 이용한 사례가 증가 하고 있다.

한편, 척추옆굽음증을 치료하기 위한 운동 요법으로 최근 슈로스 운동에 대한 치료 효과가 보고되고 있다. ${ }^{18}$ 슈로스 운동이란 1910년대 독일의 물리치료사 Katharina schroth가 척추옆굽음증 환자의 자세를 교정하기 위해 고안한 운동이다. 감각운동 법칙에 근거하여 개발된 슈로스 운동은 불균형한 자세를 교정하고 일상생활에서 교정된 자 세를 유지하게 한다. ${ }^{19}$ 슈로스 운동은 환자들의 굽이 유형에 따라 척 추옆굽음증의 3 차원적 자세 교정이 적절하게 이루어지도록 도울 수
있다. ${ }^{20}$ 구체적으로는 척추의 옆굽음과 비틀림을 교정하기 위한 역회 전(de-rotation)과 역굽힘(counter-flexion), 재뒤굽음증(re-kyphosis) 운 동ㄱㄱㄱㅘ 돌림호흡(rotational breathing)을 함께 적용하여 몸통의 변형 및 호흡능력을 개선시키는 운동방법이다.22 척추옆굽음증 환자에게 슈로스 운동을 적용한 이전 연구를 살펴보면 연구에 참여한 대부분 의 환자들이 슈로스 운동 후 통증 감소와 삶의 질 향상을 보고하였 다. 이 외에도 다양한 연구에서 슈로스 운동이 환자들의 척추옆굽음 증각도 감소에 효과적임을 입증하였다.23

이전 연구에서는 슈로스 운동과 필라테스 운동이 각각 척추교정 에 긍정적인 영향을 주는 것으로 보고되고 있다. ${ }^{24}$ 그러나 필라테스 와 슈로스 두 운동의 특징을 혼합한 운동 프로그램이 척추교정에 어 떠한 효과가 있는지를 검증한 연구는 거의 전무한 실정이다. 따라서 본 연구는 단일사례연구로 척추옆굽음증 환자에게 긍정적인 결과를 얻었던 필라테스 운동과 슈로스 운동을 본 연구에 알맞게 수정하여 척추옆굽음증을 가지고 있는 10-20대 여성 환자에게 적용하고, 해당 운동이 척추 옆굽음 각도, 몸통 돌림각, 허리 통증에 어떠한 효과를 보이는지를 검증하고자 하였다.

\section{연구 방법}

\section{1. 연구 대상}

본 연구의 대상자는 실험 전 사전 검진을 통해 정형외과 전문의로부 터 특발성 척추옆굽음증 진단을 받은 환자들 중 Cobb's angle $20^{\circ}$ 이 상의 환자들로, 2019년 3월부터 7월까지 필라테스 운동에 참여 의사 를 밝힌 광주광역시에 거주하는 10-20대 여성 3명을 대상자로 하였 다. 연구에 참여한 대상자의 일반적인 특성은 Table 1 과 같다. 대상자 1 은 29세의 직장인 여성으로 15 세 때 처음 특발성 척추옆굽음증으로 진단받은 후사설 클리닉에서 6 개월 동안 교정 및 운동치료를 받았으 나이후 허리 통증이 심한 경우에만 병원에 내원하여 물리치료 및 통 증치료를 받아왔다. 대상자 2 는 22 세 대학생으로 20 세에 특발성 척추 옆굽음증으로 최초 진단을 받았으며 정형외과 병원에서 외래로 물 리치료 및 도수치료를 3 개월가량 받아왔으나 이후 증상의 호전이 없 어 치료를 중단하였다. 대상자 3 은 18 세의 고등학생이며, 약 3 년 전 40 도 이상의 특발성 척추옆굽음증으로 진단받은 후 정기적으로 병의원

Table 1. General characteristics of the study subjects

\begin{tabular}{lccccc}
\hline Category & $\begin{array}{c}\text { Age } \\
(\mathrm{yr})\end{array}$ & $\begin{array}{c}\text { Weight } \\
(\mathrm{kg})\end{array}$ & $\begin{array}{c}\text { Height } \\
(\mathrm{cm})\end{array}$ & $\begin{array}{c}\text { BMl } \\
\left(\mathrm{kg} / \mathrm{m}^{2}\right)\end{array}$ & $\begin{array}{c}\text { Cobb's } \\
\text { angle }\left(^{\circ}\right)\end{array}$ \\
\hline Subject 1 & 29 & 49 & 163.5 & 18.4 & 22 \\
Subject 2 & 22 & 47 & 154.0 & 19.8 & 37 \\
Subject 3 & 18 & 54 & 164.0 & 20.1 & 55 \\
Average & 23 & 50 & 160.5 & 19.4 & 38 \\
\hline
\end{tabular}


에서 교정 및 운동치료를 받아왔다. 그러나 척추옆굽음증이 악화되 어 성장기가 끝난 후 $55^{\circ}$ 의 중증의 특발성 척추옆굽음증으로 진단받 았다. 대상자들은 프로그램을 실시하기 전에 연구 목적과 진행 절차 에 대하여 충분한 설명을 듣고 동의서를 작성하였으며, 미성년자의 경우 보호자의 동의를 받은 후 프로그램에 참여하였다. 연구대상자 선정 기준은 다음과 같다. 1 ) 척추옆굽음증 검사인 앞쪽 굽힘 검사 (Adam`s forward-bending test)를 실시하여 척추옆굽음증 계측기로 몸 통 돌림각(angle of trunk rotation, ATR)이 $5^{\circ}$ 이상의 변형각이 나타난 자, 2) 전신 척추 앞뒤(whole spine anterior-posterior) 단순 방사선 사진 (X-ray)을 촬영하여 Cobb's angle이 $20^{\circ}$ 이상인 자, 3) 최근 6개월 동안 규칙적인 운동프로그램에 참여한 경험이 없는 자, 4) 척추옆굽음증으 로 인한 보조기 착용이나 치료를 받은 적이 없는 자, 5) Risser 징후 5단 계로 척추 옆굽음 각이 점진적으로 증가될 가능성이 없는 자이다.

\section{2. 측정방법 및 도구}

1) 척추옆굽음증 각도(Cobb's angle)

Cobb's angle에 대한 평가는 척추의 전후면 영상을 촬영하기 위해 진 단용 X선 촬영장치인 BLD-150RK (Listem, Korea)를 사용하였으며, 의 료기관에서 전문 방사선사가 촬영하였다. 척추 굽이의 각도는 컴퓨 터 영상처리 시스템인 iView 프로그램(CAD impact, Korea)을 이용하 여 Cobb's angle을 측정하였다. 구체적으로 측정하고자 하는 굽이의

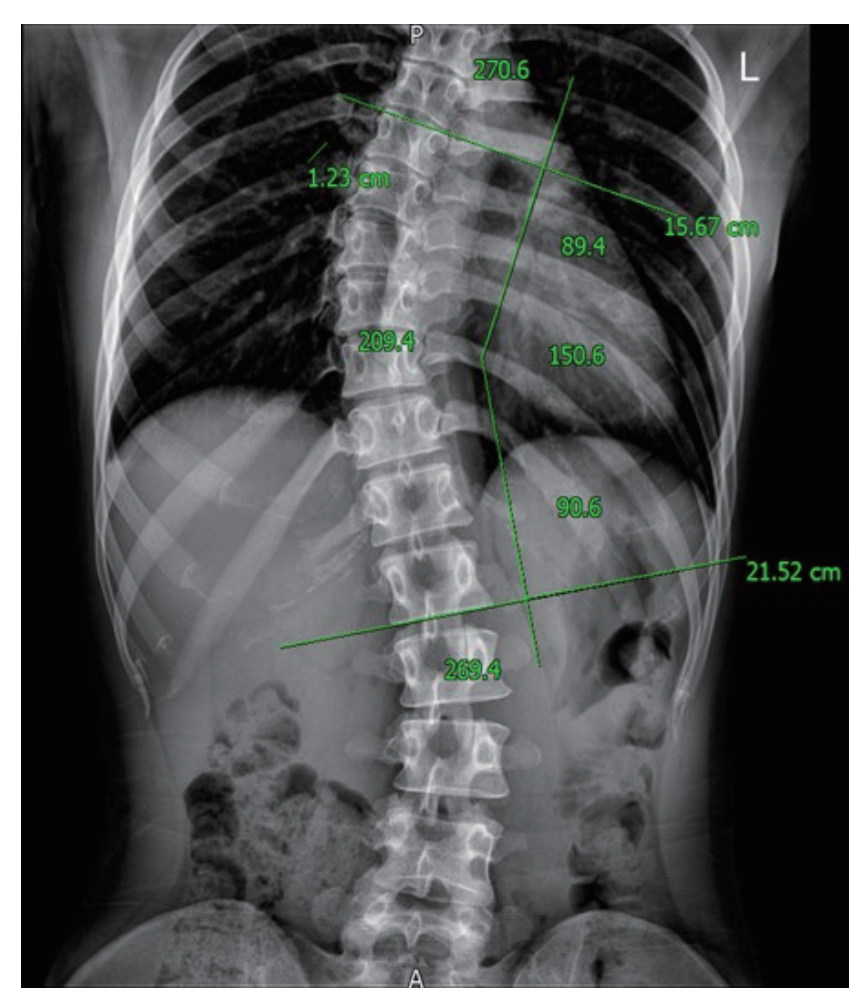

위쪽과 아래쪽의 척추뼈 몸통 중 오목면 쪽으로 가장 많이 기울어진 척추를 정하여 오목면 쪽으로 연장선을 긋고, 두 연장선에서 각각 수 직선을 그어 두 수직선이 만나는 지점에 생기는 각을 확인하는 방법 으로 Cobb’s angle을 측정하였다(Figure 1).

\section{2) 몸통 돌림각(angle of trunk rotation, ATR)}

몸통 돌림각은 Scoliometer (OSI, USA)를 이용하여 등뼈와 허리뼈의 기형적인 부분이 가장 두드러지는 부위의 몸통의 돌림을 측정하였 다. 대상자가 앞쪽 굽힘 검사(Adam's forward bending test)를 하는 동안 검사자는 앞으로 숙이는 대상자의 등과 눈높이를 같게 하고, 검사하 고자 하는 가시돌기 위에 Scoliometer를 위치하도록 하였다. 이때 가슴 부의 갈비뼈 돌출부(rib hump)와 허리부위의 돌출부(lumbar hump)에 서가장 돌출이 심한 정점부위의 몸통 돌림각을 측정하였다. ${ }^{25}$

\section{3) 허리 통증}

본 연구에서는 Fairbank 등 ${ }^{26}$ 에 의해 허리 통증환자의 증상 완화와 증 가를 측정할 수 있도록 개발된 Oswestry 허리 통증장애 지수 설문지 를 사용하였다. Oswestry 설문지는 통증관리, 개인관리, 걷기, 앉기, 서 기, 수면, 사회생활 등에 관한 10 개 문항으로 구성되어 있다. 본 연구 에서는 연구대상 중 미성년자가 포함되어 있어 성생활에 관한 문항 을 제외하고 총 9문항을 사용하였다. 모든 문항은 6개 수준으로 응답 하게 되어 있으며 총점의 범위는 9-54점이고 총점이 높을수록 허리 통증 수준이 높음을 의미한다.

\section{3. 실험절차}

본 연구에서는 단일사례 실험 연구방법(single-subject experimental research design) 중 반전연구(reversal design or ABA design)를 이용하 여 진행하였다. 총 실험 회기는 30 회로 실험은 기초선, 중재 1 , 중재 2 , 유지기로 나누어서 진행하였다. 기초선 단계에서는 중재 없이 본 연 구에서 측정하고자 하는 종속변인인 Cobb's angle, 몸통 돌림각, 허리 통증 수준을 측정하였고 중재 단계에서는 10 주간의 슈로스 운동 기 반의 기구필라테스 프로그램을 실시한 이후 각각 5 주, 10 주 후 치료 결과를 측정하였으며, 유지기는 중재 종결 후 5 주 뒤 종속변인을 측 정하였다. 기초선은 Cobb's angle 측정을 위한 X-ray 촬영 외 다른 종 속변인들은 하루에 한번씩 3일 동안 측정하여 안정된 자료를 확인 후 설정하였으며 중재 1 , 중재 2 와 유지기 단계에서는 각 단계별로 1 회 씩 종속변인을 측정하였다. 본 연구의 대상자 치료와 결과 측정은 측 정자 간에 발생할 수 있는 오염변인을 최소화하기 위하여 동일한 연 구자에 의하여 실시되었으며, 연구 기간은 2019년 3월 25일부터 7월 14 일까지 진행되었다.

Figure 1. Measurement for Cobb's angle. 


\section{4. 중재 프로그램}

전체적인 운동 프로그램의 구성은 1 회 60 분으로 준비 운동(15분), 본 운동(40분), 정리 운동(5분)으로 이루어진다. 본 운동(main Exercise)은 개인의 굽이의 형태에 맞추어 적용된 슈로스 운동과 기구 필 라테스 운동을 혼합하여 진행하였으며, 각각의 운동을 실시할 때 매 번 호흡과 함께 진행하도록 하였다. 운동 강도는 Borg의 운동자각도 (rating of perceived exertion, RPE)를 이용하여 중재 1 기간에는 RPE 11 (알맞음)의 강도에서부터 시작하여 중재 2 기간에는 RPE 15 (힘듦)의 강도까지 점진적인 부하로 실시하였다. ${ }^{27}$ 준비 운동(Warm up)은 시상 면상의 바른 정렬과 척추옆굽음증 치료를 위한 운동으로 구성하였 다. 시상면상의 정렬을 바르게 하기 위하여 운동으로는 Physio-logic (시상면 정렬운동)과 $3 \mathrm{D}$ made easy 프로그램으로 구성하였다. Physio$\operatorname{logic}$ 운동 적용은 척추옆굽음증 치료 결과를 향상시킬 수 있다고 하 였으며, 일상활동에서 유래된 3D made easy 프로그램은 배우기 쉽고 경미한 굽이나 Physio-logic 프로그램과의 조합에 이상적이라고 하였 다. ${ }^{28}$ 정리 운동(Cool down)은 척추 자세 교정과 가슴우리의 움직임 및 관절의 가동범위를 향상 시킬 수 있도록스트레칭을 실시하였다. ${ }^{28}$

대상자들에게 자신의 몸을 3 차원적으로 잘 인지할 수 있도록 충 분한 설명을 하고, 교정된 자세에서 정렬이 무너지지 않도록 주의하 였다. 환자 스스로 일상생활 속에서도 교정된 자세를 유지하는 것이 매우 중요함으로 굽이 형태에 따라 바른 일상생활 활동자세(앉은 자 세, 선 자세와 보행 등)를 지속할 수 있도록 행동을 변화시키는 전략 을 수립하였다. ${ }^{28}$ 모든 운동은 Pilates Instructor 자격증이 있는 3 년 차 이상의 물리치료사의 지도하에 실시되었다(Table 2, Figure 2).

\section{1) 운동 프로그램}

(1) Physio-logic Exercise

허리척추의 앞굽음 가동성 및 등척추의 뒷굽음 가동성 개선을 위한 운동으로 환자는 의자에 바른 자세로 앉아 골반을 앞기울임을 취하
여 허리척추의 앞굽음을 만들어준다. 그리고 호흡을 들이마시고 내쉬 면서 등척추의 뒷굽음을 만든다는 느낌으로 봉을 앞으로 밀어낸다.

(2) 3D Made easy Exercise

대상자는 척추를 신장시킨다는 느낌으로 곧게 편 상태로 서서 오른 쪽 무릎을 약간 구부리고 볼록면쪽의 어깨를 후·하방으로 움직여 어깨뼈를 고정하고 볼록한 부분을 수축하게 한다. 그리고 오목면 부 위에 공기를 넣어준다는 느낌으로 숨을 들이마신 후 볼록면 부분을 수축한다는 느낌으로 강하게 숨을 내쉬다.

(3) Teaser

머리를 푸시스루바 쪽을 향하게 두고 Supine position에서 양손을 길 게뻗어 바를 잡고 양무릎은 테이블 탑자세를 유지한다. 들이마시고 내쉬는 호흡에 배꼽을 척추 쪽으로 당기는 힘을 주며 동시에 양손은 바를 밀어내며 머리-등-허리 순으로 분절하며 올라간다. 이때 양다리 는 사선으로 뻗어주며 전체적으로 $\mathrm{v}$ 자를 만들어 유지 후 들이마시고 내쉬는 호흡에 시작 자세로 돌아온다.

\section{(4) One Leg Bridge}

리포머를 이용하여 Bridge exercise 방식으로 들이마시는 호흡에 복부 를 잡아준 상태에서 골반-허리-등-어깨뼈 아래각까지 분절을 이용하 여 들어 올린다. 이때 한쪽 무릎은 반대쪽 무릎과 동일한 높이에서 폄 시키고 다리를 전방으로 뻗는 느낌으로 유지하면서 마시고 내쉬 는 호흡에 다리를 내리고 척추 분절을 이용하여 내려놓는다.

(5) Swan Dive

바렐 정상에 골반 앞쪽을 고정 후 엎드려 양손은 Ledder를 잡고 살짝 저항을 준다. 이때 팔꿈치는 살짝 구부려 몸통을 바닥 쪽으로 기울이 고, 다리는 가쪽 돌림 시켜 고정 후 천장 쪽으로 들어 올려준다.

Table 2. The pilates exercise program based on schroth exercise

\begin{tabular}{|c|c|c|c|c|}
\hline & Apparatus & Exercise & Set & RPE \\
\hline \multirow[t]{2}{*}{ Warm up (15 min) } & & Physio-logic Exercise & & \\
\hline & & 3D Made easy Exercise & & \\
\hline \multirow[t]{7}{*}{ Main Exercise (40 min) } & Trapeze table & Teaser & 15 reps $\times 2$ set & $11-15$ \\
\hline & Reformer & One Leg Bridge & & \\
\hline & Ladder Barrel & Swan Dive & & \\
\hline & Combo Chair & Scapula Mobilization & & \\
\hline & & (Rotation/Push-up) & & \\
\hline & Schroth Exercise & Fifty Times & 50 reps & \\
\hline & & Door Handle Exercise & & \\
\hline \multirow[t]{2}{*}{ Cool down (5 min) } & & Muscle Cylinder & & \\
\hline & & Spine Stretching & & \\
\hline
\end{tabular}




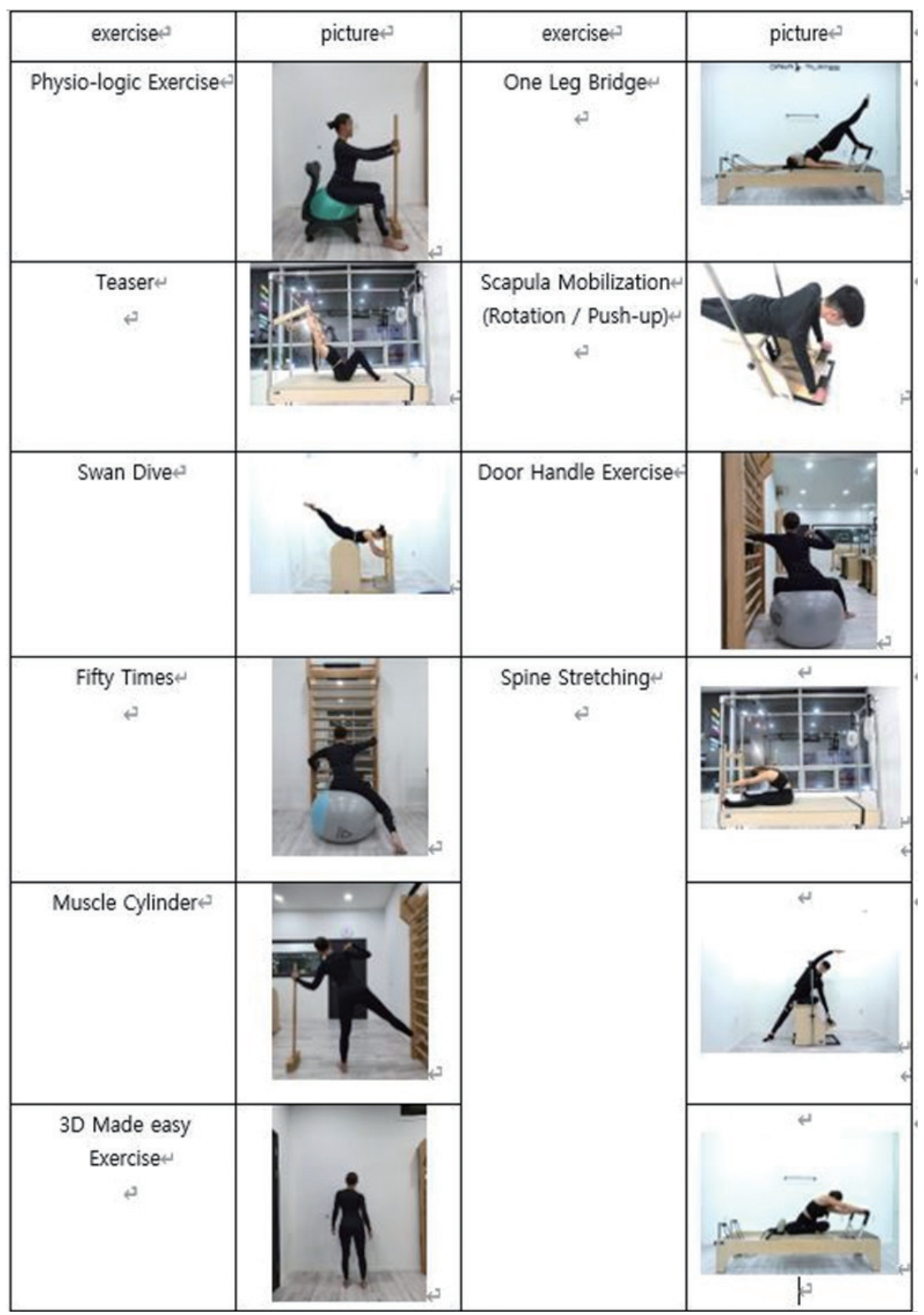

Figure 2. Exercise.

(6) Scapula Mobilization (Rotation/Push-up)

체어에 Prone position으로 양손을 페달 위에 놓고 몸통은 고정시킨 다. 이때 양손을 교차로 뻗어 어깨뼈를 내밈과 들임 시켜준다.

(7) Fifty Times

환자는 월바(Wall Bar)를 마주 보고 오른쪽 골반은 약간 아래로 내려 주는 자세로 짐볼에 앉는다. 등척추의 볼록면 쪽 팔을 눈높이의 월바 를 잡고 뒤쪽으로 당기며 오른쪽 가슴을 앞으로 내밀게 한다. 이때 오 목면 쪽 팔은 허리 높이의 월바를 잡고 아래로 누르면서 가쪽으로 밀
어내 준다. 이때 오목한 부위로 공기를 넣어준다는 느낌으로 숨을 들 이마시고 볼록한 부위를 넣는다는 느낌으로 강하게 수축시키며 숨 을 내쉰다.

\section{(8) Door Handle Exercise}

환자는 월바 앞에서 등척추의 오목면이 월바를 향하도록 짐볼에 앉 는다. 안정된 자세를 위해서 엉덩관절은 벌림 및 가쪽돌림 시킨다. 오 목면 쪽의 손은 어깨 높이의 바 사이 틈을 통해 허리 위치에 있는 바 를 잡는다. 이때 볼록면 쪽의 손은 같은 쪽 어깨를 잡아 양쪽 팔꿈치 
와 위팔을 월바에서 가능한 수직으로 향하게 한다. 월바에서 떨어져 있는 시작 자세로 인해 등척추의 오목면 쪽에 긴장 및 과교정을 유도 한다. 이후 오목한 부위 가쪽 및 등 방향으로 공기를 넣어준다는 느낌 으로 숨을 들이마시고 볼록한 부위를 넣는다는 느낌으로 강하게 수 축시키며 숨을 내쉰다.

\section{(9) Muscle Cylinder}

등척추의 볼록면 쪽 다리를 편 상태로 바에 올리고 머리, 몸통, 다리 가 평행하게 몸통을 기울여 서게 한다. 등척추의 오목한 부분의 손으 로 봉을 가볍게 잡고 반대 측 볼록면 부위의 손은 어깨에 올리게 하 여 몸통의 좌. 우가 서로 평행하게 유지한다. 이때 환자는 등척추의 오목한 부분에 공기를 넣어준다는 느낌으로 숨을 들이마시고, 내쉴 땐 볼록한 부분을 수축시킨다는 느낌으로 강하게 내쉬는 호흡을 하 였다.

\section{(10) Spine Stretching}

Spine stretching은 기구마다 각각 적용 가능한 운동이다. 첫 번째는 Spine Stretching 방법을 이용한 척추 스트레칭법으로 척추 정렬을 맞 추고 양 발바닥은 수직 바에 놓고 무릎은 펴내 준다. 양손은 손등이 얼굴 방향을 볼수 있게 바를 잡은 상태에서 복부를 수축시키는 동시 에 바를 멀리 밀어내며 머리-등-허리 순으로 분절하며 내려간다. 두 번째는 체어를 이용한 머메이드(Mermaid) 운동 방식으로 환자는 양 팔을 벌리고 체어에 앉는다. 이때 체어 페달 쪽 다리를 구부리고 반대 측 다리는 가쪽돌림 시킨 후 뻗어준다. 몸통을 체어의 페달 방향으로 가쪽 굽힘 시키면서 손으로 페달을 누르고 반대 측 팔은 사선 방향으 로 길게 뻗어주면서 옆구리를 스트레칭시킨다. 세 번째는 리포머를 이용해 머메이드 방식으로 몸통을 앞으로 기울이며 양 손은 풋바 (foot bar)를 잡고 유지한다. 이때 풋바를 잡은 손을 뻗어 캐리지(Carriage)를 밀어주면서 반대 측 옆구리를 스트레칭 한다.

\section{5. 자료분석}

본 연구에서는 대상자별로 측정된 종속변인(Cobb's angle, Scoliometer 각도, Oswestry 허리 통증장애지수)의 평균값을 기술통계량으로 제
시하고 시각적 그래프를 통하여 기초선, 중재 1 , 중재 2 , 유지기의 변 화를 비교하였다. 각 기간 동안 평가는 5 주 후, 10 주 후에 기초선과 동 일한 방법으로 실시하였으며, 유지기는 중재 종결 5주 후에 종속변인 의 개선 및 유지를 알아보기 위하여 기초선과 동일한 조건에서 유지 검사를 실시하였다.

\section{연구 결과}

\section{Cobb's angle의 변화}

슈로스 운동 기반의 기구필라테스 프로그램 적용 전. 후 각 대상 자 별로 기초선과 중재 그리고 유지기 동안 Cobb's angle의 변화를 Table 3 에 제시하였다. 대상자 1 의 Cobb's angle은 기초선에서 $25.0^{\circ}$, 중재 1 에서는 변화가 없었으나 중재 2 에서 $22.0^{\circ}$ 로 감소했으며, 유지기에서 는 동일하게 $22.0^{\circ}$ 를 유지하였다. 대상자 2 는 기초선에서 $38.0^{\circ}$, 중재 1 에서 $37.0^{\circ}$, 중재 2 에서 $34.5^{\circ}$, 유지기에서는 $30.5^{\circ}$ 로 시기별로 Cobb's angle이 낮아졌다. 대상자 3 은 기초선 $55.0^{\circ}$, 중재 1 에서 $52.0^{\circ}$, 중재 2 에 서 $45.0^{\circ}$, 유지기에서는 $41.5^{\circ}$ 로 낮아졌다(Figure 3 ).

\section{2. 몸통 돌림각의 변화}

슈로스 운동 기반의 기구필라테스 프로그램 적용 전, 후 각 대상자 별로 기초선과 중재 그리고 유지기 동안 몸통 돌림각의 변화를 Table 3 에 제시하였다. 대상자 1 은 기초선에서 $15^{\circ}$, 중재 1 에서 $12^{\circ}$, 중재 2 와

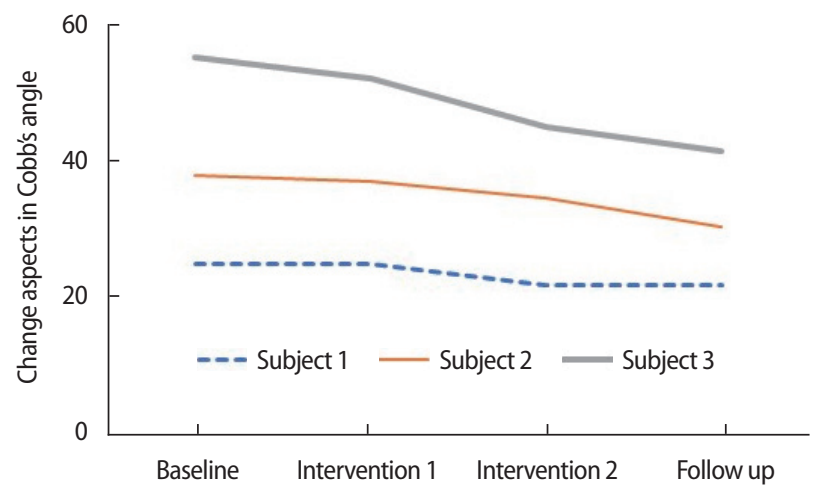

Figure 3. Change aspects in Cobb's angle.

Table 3. Change aspects in Cobb's angle, ATR, LBP before and after the program application

\begin{tabular}{|c|c|c|c|c|c|c|c|c|c|c|c|c|}
\hline \multirow[b]{2}{*}{ Category } & \multicolumn{3}{|c|}{ Baseline } & \multicolumn{3}{|c|}{ Intervention 1} & \multicolumn{3}{|c|}{ Intervention 2} & \multicolumn{3}{|c|}{ Follow up } \\
\hline & $\begin{array}{l}\text { Cobb's } \\
\text { angle }\end{array}$ & ATR & LBP & $\begin{array}{l}\text { Cobb's } \\
\text { angle }\end{array}$ & ATR & LBP & $\begin{array}{l}\text { Cobb's } \\
\text { angle }\end{array}$ & ATR & LBP & $\begin{array}{l}\text { Cobb's } \\
\text { angle }\end{array}$ & ATR & LBP \\
\hline Subject 1 & $25.0^{\circ}$ & $15^{\circ}$ & 17 & $25.0^{\circ}$ & $12^{\circ}$ & 12 & $22.0^{\circ}$ & $11^{\circ}$ & 15 & $22.0^{\circ}$ & $11^{\circ}$ & 13 \\
\hline Subject 2 & $38.0^{\circ}$ & $16^{\circ}$ & 19 & $37.0^{\circ}$ & $14^{\circ}$ & 15 & $34.5^{\circ}$ & $10^{\circ}$ & 19 & $30.5^{\circ}$ & $10^{\circ}$ & 16 \\
\hline Subject 3 & $55.0^{\circ}$ & $20^{\circ}$ & 13 & $52.0^{\circ}$ & $15^{\circ}$ & 11 & $45.0^{\circ}$ & $14^{\circ}$ & 10 & $41.5^{\circ}$ & $13^{\circ}$ & 10 \\
\hline Average & $39.3^{\circ}$ & $17^{\circ}$ & 15 & $38.0^{\circ}$ & $14^{\circ}$ & 13 & $33.8^{\circ}$ & $12^{\circ}$ & 15 & $31.3^{\circ}$ & $11^{\circ}$ & 13 \\
\hline
\end{tabular}

LBP: low back pain level. 


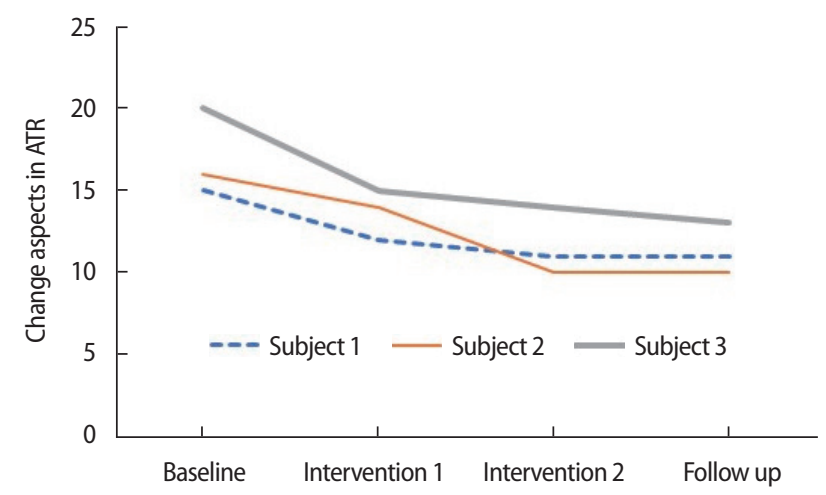

Figure 4. Change aspects in ATR.

유지기에는 $11^{\circ}$ 로 낮아졌으며, 대상자 2 도 마찬가지로 기초선에서 $16^{\circ}$, 중재 1 에서 $14^{\circ}$, 중재 2 와 유지기는 $10^{\circ}$ 로 낮아졌다. 대상자 3 은 기 초선에서 $20^{\circ}$, 중재 1 에서 $15^{\circ}$, 중재 2 에서 $14^{\circ}$, 유지기에서 $13^{\circ}$ 로 지속적 으로 낮아졌다(Figure 4).

\section{3. 허리 통증 수준의 변화}

허리 통증 수준의 변화에서 대상자 1 은 기초선에서 17 점, 중재 1 에 서 12점, 중재 2에서 15점, 유지기에서 13점으로 중재 1이 기초선에 비 해 많이 낮아졌으나 중재 2에서는 중재 1에 비해 올랐으며 유지기에 는 다시 다소 낮아지는 양상을 보였다. 대상자 2 도 중재 1에서 15점으 로 기초선인 19점에 비해 많이 낮아졌으나 중재 2에서는 19점으로 다 시 기초선 만큼 높아졌으며 유지기에는 16점으로 다시 낮아졌다. 반 면, 대상자 3 은 기초선 13 점, 중재 1 에서 11점, 중재 2 에서 10 점, 유지기 에서 10점으로 지속적으로 낮아졌다(Figure 5).

\section{고 찰}

본 연구는 슈로스 운동과 필라테스 운동의 핵심적인 내용을 결합 시켜 특발성 척추옆굽음증의 증상을 개선하기 위한 운동 프로그램 을 개발하였으며, 중증 특발성 척추옆굽음증 환자에게 적용해 특발 성 척추옆굽음증 환자의 치료적 중재 효과를 규명하고자 하였다.

이전 연구에서 슈로스 운동그룹과 필라테스 운동그룹을 비교하였 을 때 두 운동 모두 Cobb's angle의 감소를 보고하였으며, 또 다른 연 구에서 특발성 척추옆굽음증 환자를 대상으로 필라테스 운동, 자세 습관 교육 병행, 무처치를 각각 그룹으로 할당하여 각각 12 주간 적용 하였을 때, 필라테스 집단과 자세 교육을 병행한 집단 모두에서 Cobb's angle이 유의하게 감소하였음을 확인하였다. ${ }^{29,30}$ 본 연구에서 는 슈로스 운동을 기반으로 한 기구 필라테스 프로그램을 적용하였 으며 척추옆굽음증 환자의 Cobb's angle을 평균 $39.3^{\circ}$ 에서 $31.3^{\circ}$ 로 줄 이는 결과를 보였다.

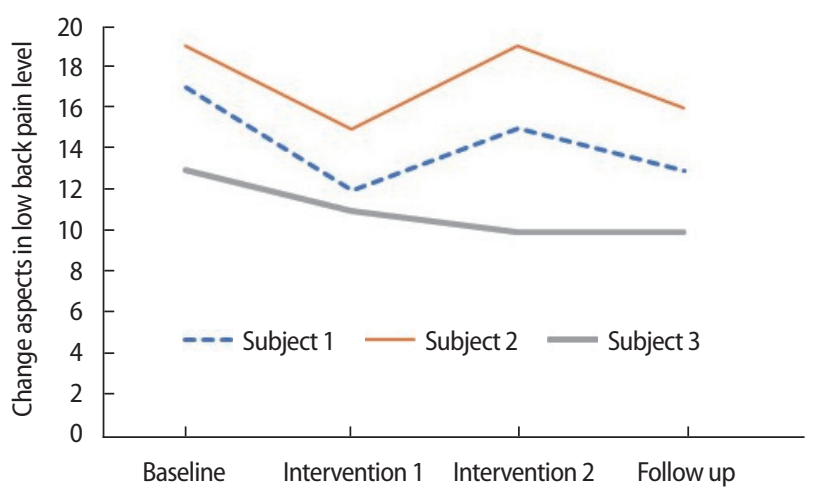

Figure 5. Change aspects in LBP.

슈로스 운동 기반의 정적 척추 옆굽음 운동과 비대칭성 척추 옆굽 음 운동을 적용하여 특발성 척추옆굽음증 환자에게 미치는 효과를 비교한 이전 연구에서 슈로스 운동을 기반으로 한 그룹이 상대적으 로 더 나은 척추 옆굽음각 개선을 나타냈다고 하였다.' 이전 연구에서 수술적 치료가 요구되는 13 세의 청소년 특발성 척추옆굽음증 환자 를 대상으로 12 주간의 슈로스 운동을 적용해 등뼈의 Cobb's angle이 $45.8^{\circ}$ 에서 $26.7^{\circ}$ 로 허리뼈의 Cobb's angle은 $30.5^{\circ}$ 에서 $19.1^{\circ}$ 로 감소됨을 확인하였다. ${ }^{31}$ 이러한 현상은 슈로스 운동이 이마면에서 중점을 둔 2 차원적인 운동법이 아닌 환자에 대한 자세한 분석을 토대로 호흡패 턴에 대한 교정을 포함하는 3차원적인 운동이며, 호흡패턴을 변화시 키는 슈로스 운동의 특성이 갈비뼈의 가동성을 증진시켜 오목한 신 체부위를 확장시켜 척추를 회전시키는데 기여했기 때문이라고 하였 다. ${ }^{31}$ 이처럼 슈로스 운동은 척추옆굽음증을 유발시키는 이차적인 요 인을 부분적으로 회복시키는데 효과적이며, ${ }^{32}$ 필라테스 운동은 척추 배열을 바르게 만들어 주기 위해 필요한 근력향상과 자세교정 인식 에 긍정적인 효과를 보고하였다. ${ }^{33}$ 따라서 이전 연구와 유사한 결과 를 나타낸 본 연구 결과 역시 척추옆굽음증을 유발시키는 이차적인 요인을 억제하고 척추배열을 바르게 만들기 위해 필요한 근력의 향 상과 자세교정 인식을 증진시킴으로써 Cobb's angle을 개선시킨 것으 로 사료된다.

본 연구 결과, 슈로스 운동을 기반으로 한 기구 필라테스 운동은 척추옆굽음증 대상자의 몸통 돌림각을 평균 $17^{\circ}$ 에서 $11^{\circ}$ 로 개선시키 는 것으로 나타났다. 이러한 결과는 성장기 특발성 척추옆굽음증 여 학생에게 슈로스 운동과 필라테스 운동을 적용하여 그 효과를 비교 했던 이전 연구 결과와 일치한다..$^{30}$ 다수의 선행연구를 통해 슈로스 운동이 척추옆굽음증을 가진 환자의 몸통 돌림각 교정에 효과가 있 음을 확인하였고, ${ }^{34}$ 필라테스 운동 또한 척추옆굽음증 환자의 옆굽 음증 정도와 통증감소, 신체 구성과 자세 교정을 통해 전반적인 각도 를 개선시키는데 효과가 있음을 확인하였다. ${ }^{35}$ 이런 이유들로 본 연구 의 슈로스 운동을 기반으로 한 기구필라테스 운동이 대상자들의 몸 
통 돌림각을 개선시킨 것으로 사료된다.

Dorado 등 36 은 건강한 성인 여성에게 36 주간 필라테스 운동을 적용 한 결과 배곧은근과 배가로근의 근육량 증가를 유도한다고 보고하였 다. 또한 선행 연구에서 만성허리 통증을 가진 환자들에게 필라테스 운동을 적용했을 때 환자들의 통증이 감소되었으며, 이는 필라테스 운동이 중간볼기근, 큰볼기근, 배곧은근, 척추세움근 등의 근활성도 를 증가시켜 허리부위 안정화에 기여한 것으로 설명하였다. ${ }^{37}$ 이처럼 필라테스 운동은 척추안정화에 영향을 미치는 코어 근육을 강화시 키는데 효과적이며, 허리를 지지해주는 깊은 층의 근육들이 단련되 어 허리 통증을 감소시키고, 척추 기능을 개선시키는 효과를 볼수 있 다. 필라테스 운동은 근력 향상을 기반으로 균형감각 증진을 도모할 수 있는 매우 효율적인 운동방법이며, 임산부를 비롯해 만성 허리 통 증을 가진 환자들에게도 적용 가능한 안전한 재활운동이다. ${ }^{38}$ 따라서 이전 연구와 유사한 본 연구 결과 역시 이러한 이유로 대상자들의 허 리 통증을 개선시킨 것으로 사료된다. 39,40 다만, 대상자 1 과 2 는 중재 2 기간 동안 허리 통증이 증가한 것으로 나타났다. 두 대상자는 모두 학 생으로 중재 2 적용 기간에 시험 기간이 포함되어 있었다. 앉아있는 시간이 증가하는데 비해 활동량이 감소하고, 스트레스가 가중되면서 허리 통증이 심해진 것으로 보인다. 이는 시험 기간이 끝나고 난 후인 유지기에 다시 허리 통증 수준이 감소하는 결과로 확인할 수 있었다. 대상자에 따라 변화의 양상은 다르나 프로그램 적용 전과 후인 기초 선과 유지기 수치를 비교하면 평균 15 에서 13으로 감소하였으며 해당 프로그램이 허리 통증 감소에 효과적임을 알 수 있었다.

위와 같은 결과를 종합해 볼 때 슈로스 운동을 기반으로 한 기구 필라테스 프로그램은 특발성 척추옆굽음증 환자들의 Cobb's angle과 몸통 돌림각을 감소시키는데 효과적이며, 이와 함께 허리 통증 수준 을 감소시키는데 도움이 되는 것으로 사료된다.

본 연구의 제한점은 다음과 같다. 첫째, 본 연구는 단일사례 실험 연구로 연구대상자가 적어 본 연구 결과를 일반화 시키는데 제한이 된다. 향후 연구에서는 대상자를 확대하고 대조군을 설정한 연구가 필요하다. 둘째, 본 연구에서는 종속변인에 영향을 줄 수 있는 중재기 간 동안 대상자들의 일상생활을 철저히 통제하지 못하였다. 향후 연 구에서는 중재 프로그램의 장기간의 효과를 평가하기 위해 프로그 램 적용 기간을 연장하여 특발성 척추옆굽음증에 대한 장기적인 효 과를 규명하는 연구가 필요하다.

본 연구에서는 20 도 이상의 특발성 척추옆굽음증이 있는 여성 환 자들을 대상으로 15 주간의 슈로스 운동을 기반으로 한 기구필라테 스 운동프로그램이 Cobb's angle, 몸통 돌림각, 허리 통증에 미치는 영 향에 대해 검증하였다. 연구 결과를 종합해보면 운동 전, 후에 따른 슈로스 운동을 기반으로 한 기구필라테스 운동이 특발성 척추옆굽 음증 환자의 Cobb's angle, 몸통 돌림각, 허리 통증을 개선하는데 효
과적으로 나타났으며, 10 주간의 중재 이후 5 주간의 유지기에서도 점 진적인 개선이 나타났다. 이러한 결과를 토대로 $20^{\circ}$ 이상의 중등도의 특발성 척추옆굽음증 환자의 치료에 슈로스 운동을 기반으로 한 기 구필라테스 운동은 효과적인 중재방법이라고 할 수 있다.

\section{REFERENCES}

1. Kong BJ. A comparison on the influences of schroth-based static scoliosis exercise and asymmetric scoliosis exercise on the patients with scoliosis. Daegu University. Dissertation of Doctorate Degree. 2014.

2. Lee JW. Effects of dynamic neuromuscular stabilization exercise and Schroth exercise on Cobb's angle, respiratory function and balance in scoliosis patients. Hanseo University. Dissertation of Doctorate Degree. 2018.

3. Anderson SM. Spinal curves and scoliosis. Radiol Technol. 2017;79(1): 44-65.

4. Mooney V, Brigham A. The role of measured resistance exercises in adolescent scoliosis. Orthopedics. 2003;26(2):167-71.

5. Kwon JE, Cho YC, Han JK et al. The effects of pilates reformer exercise on women's foot pressure, sagittal alignment and forward head posture. Korean J Sports Sci. 2019;28(6):1395-403.

6. Lehnert-Schroth C. Three dimensional treatment for scoliosis: a physiotherapeutic method. 8th ed. Seoul, Yeongmunsa, 2015;4:45-59.

7. Park SE. The effect of schroth treatment on cobb's angle and pulmonary function variables of idiopathic scoliosis patients. Korea University. Dissertation of Master's Degree. 2012.

8. Hawes MC. The use of exercises in the treatment of Scoliosis: an evidence-based critical review of the literature. Pediatr Rehabil. 2003;6(34):171-82.

9. Hee HH. The effect of pilates exercise program on health related physical fitness in salaried women. Korean National Sport University. Dissertation of Master's Degree. 2007.

10. Latey P. The Pilates method: history and philosophy. J Bodyw Mov Ther. 2001;5(4):275-82.

11. Jeong CW, Ann GY, Lee JW. Effects of pilates with foam roller on body composition, senior fitness, and hip joint rom in rural elderly women. J Phys Growth Moto Develop. 2011;19(2):160-70.

12. Park KH. The effect of dynamic stability exercise with pilates on balance, gait and trunk muscle activity of patients with chronic stroke. Daegu University. Dissertation of Doctorate Degree. 2016.

13. Park SJ, Kim HN, Jo JH. The effects of the core strenghtening-pilates exercise on the performer's physical self-perception and performance confidence of college students majoring in dance. KSDS. 2013;30(1): $107-21$.

14. Yu BK, Jung SY, Kim MN et al. The effects of Pilates mat exercise in 8 weeks on twenty-aged women's body composition, lumbar muscle strength and flexibility. AOSPT. 2008;4(1):61-6.

15. Im KC, Lee CJ, Roh DJ. Effect of pilates exercise on the cobb's angle, physical fitness and lumbar muscle in scoliosis middle school girls. Korean J Sport Sci. 2015;24(1):1161-71.

16. Kwon HH. Effects of pilates exercise in correcting body alignment and postural patterns among elementaly school girls. Ewha Womans Uni- 
versity. Dissertation of Master's Degree. 2014.

17. Lee J, Seo SJ. A study of middle aged women, on their muscle activity and subjective analysis of the body according to pilates positions. KSDS. 2016;33(4):109-23.

18. Otman, S, Kose N, Yakut Y. The efficacy of Schroth's 3-dimensional exercise therapy in the treatment of adolescent idiopathic scoliosis in Turkey. Saudi Med J. 2005;26(9):1429-35.

19. Weiss HR. The method of katharina schroth - history, principles and current development. Scoliosis. 2011;6(1):1-22.

20. Negrini S, Antonini G, Carabalona R et al. Physical exercises as a treatment for adolescent idiopathic scoliosis. a systematic review. Pediatr Rehabil. 2003;6(3-4):227-35.

21. Lee JH, Kim SY. Comparative effectiveness of schroth therapeutic exercise versus sling therapeutic exercise in flexibility, balance, spine angle and chest expansion in patient with scoliosis. J Korean Soc Phys Med. 2014;9(1):11-23.

22. Rigo M, Quera-Salvá G, Villagrasa M et al. Scoliosis in tensive out-patient rehabilitation based on schroth method. Stud Health Technol Inform. 2008;135:208-27.

23. Borysov M, Borysov A. Scoliosis short-term rehabilitation (SSTR) according to 'Best Practice' standards-are the results repeatable? Scoliosis. 2012;7(1):1-5.

24. Seo JH, Hong SG. The pilates effects about scoliosis. J Korean Soc Radiol. 2014;8(7):397-400.

25. Lee CS, Kim YT, Lee CK. Morphological analysis of the cervical spinal cord, dural tube, and spinal canal by magnetic resonance imaging in normal korean adults. J Korean Orthop Assoc. 1999;34(2):265-71.

26. Fairbank JC, Couper J, Davies JB et al. The oswestry low back pain disability questionnaire. Physiotherapy. 1980;66(8):271-3.

27. Borg GA. Psychophysical bases of perceived exertion. Med Sci Sports Exerc. 1982;14(5):377-81.

28. Weiss HR, Klein R, Hollaender M. ADL based scoliosis rehabilitation-the key to an improvement of time-efficiency? Stud Health Technol Inform. 2006;123:594-8.

29. Sung EH. The effect of 12 week's pilates and postural patterns training program on thoracic cobb's angle, static balance, thoracic mobility and postural patterns correction in adolescents with scoliosis. Korea National Sport University. Dissertation of Master's Degree. 2013.

30. HwangBo PN. Comparisions of effects of schroth exercise and pilates exercise to female students with growing idiopathic scoliosis. Daegu University. Dissertation of Doctorate Degree. 2015.

31. Lee SG, Lim SK, The case study of exercise therapy using schroth method in a patient with adolescent idiopathic scoliosis. A J Kinesiol. 2013; 15(4):155-67.

32. Lehnert-Schroth C. Three dimensional treatment for scoliosis: a physiotherapeutic method. 8th ed. Seoul, Yeongmunsa, 2015;11:211-24.

33. Kim Emery, Serres SJ De, Mcmillan A et al. The effects of a pilates training program on arm-trunk posture and movement. Clin Biomech. 2010;25 (2):124-30.

34. Chae EY. Effects of closed kinetic chain and schroth exercise on displacement of spine and plantal pressure in wamen with scoliosis. Daegu University. Dissertation of Master's Degree. 2019.

35. Muscolino JE, Cipriani S. Pilates and the "powerhouse". J Bodyw Mov Ther. 2004;8(1):15-24.

36. Dorado C, Calbet JA, Lopez-Gordilllo A et al. Marked effects of Pilates on the abdominal muscles: a longitudinal magnetic resonance imaging study. Med Sci Sports Exerc. 2012;44(8):1589-94.

37. Natour J, Cazotti LA, Ribeiro LH et al. Pilates improves pain, function and quality of life in patients with chronic low back pain: a randomized controlled trial. Clin Rehabil. 2015;29(1):59-68.

38. Baek SG. The effects of 12 weeks pilates mat exercise on body composition, lumbar muscle strength, low back pain and pregnancy stress in pregnant women. Journal of KOEN. 2020;14(6):259-67.

39. Choi BH, Kim CH. Effect of pilates mat exercises on low back pain, lumbar muscular strength of elderly, pain scale and body composition. J Korea Sport Res. 2006;17(5):633-42.

40. Hur JG. The effects of mat exercise and ball exercise on Oswetry Disability Index,balance, and multifidus cross sectional areas in patients with chronic lower back pain. Korean J Sport Sci. 201 1;9(3):525-34. 